\title{
Investasi Pasar Modal Syariah Indonesia: Peluang Dan Tantangan Ditengah Pandemi Covid-19 (Dalam Perspektif Fatwa Ulama)
}

\author{
Devie Rachmat ${ }^{1}$, Ade Pratiwy Susanti ${ }^{2}$ \\ Dosen Fakultas Hukum Universitas Lancang Kuning Pekanbaru, Indonesia, Email : devie@unilak.ac.id \\ Dosen Fakultas Hukum Universitas Lancang Kuning Pekanbaru, Indonesia, Email : \\ ade_pratiwi_susanty@gmail.com
}

\section{Article Info}

\section{Article History:}

Received : 30-03-2021

Revised : 20-05-2021

Accepted : 10-07-2021

Published : 01-11-2021

\section{Keywords:}

Islamic

Capital markets

Covid-19

\begin{abstract}
In classical Islamic literature not foud the terminology of Islamic Capital markets. As Muslims need to be sure about investing in the Islamic capital market according to the teachings of his religion. The description related issues raised in this article: 1. What do Muslims think about sharia capital market? 2. What is the Fatwa of the National Sharia Council governing sharia investment activities? 3. How is the challenge of sharia capital market investment in Indonesia in the midst of the Covid-19 Pandemic. In order to critique in this article meets the requirements, the authors define the methods of scientific research, which is a normative legal research. As for taking the necessary legal material is secondary to the type of data is a primary law and secondary law. This article concludes the discussion of the Islamic capital market transactions can be done through: Akad buying and selling of securities, does not contain elements of usury, no falsehood, seeking grace of God, to be trustworthy, mutual blessing and not mutually zalim. Muslim thinking on Islamic capital market has a different opinion in assessing whether securities transactions in the Islamic capital market contain elements which are prohibited by sharia. 40/DSN-MUI/X/2003 dated October 4, 2003 on Capital Markets and the General Guidelines for the Application of Sharia in the Capital Market has determined criteria for investment products that in accordance with the teachings of Islam.
\end{abstract}

\footnotetext{
Abstrak

Bagaimana dalil-dalil yang dapat dijadikan landasan pasar modal syariah? bagaimana tafsir maudhu'i tentang beberapa efek pasar modal syariah? bagaimana pemikiran Muslim tentang pasar modal syariah? bagaimana Fatwa Dewan Syariah Nasional yang mengatur tentang kegiatan investasi syariah? Agar kupasan dalam artikel ini memenuhi persyaratan ilmiah maka penulis menentukan metode penelitian, yaitu penelitian hukum normatif. Pembahasan artikel ini menyimpulkan transaksi pasar modal syariah dapat dilakukan melalui: Akad jual beli surat berharga, tidak mengandung unsur riba, tidak ada kebatilan, mencari karunia Allah, bersikap amanah, saling ridho dan tidak saling mendzalimi.Telah ada Fatwa Dewan Syariah Nasional yang mengatur tentang kegiatan investasi syariah adalah Nomor : 40/DSN-MUI/X/2003 tanggal 4 Oktober 2003 tentang Pasar Modal dan Pedoman Umum Penerapan Prinsip Syariah di Bidang Pasar Modal telah menentukan tentang kriteria produk-produk investasi yang sesuai dengan ajaran Islam.
} 


\section{PENDAHULUAN}

Ekonomi Islam di Indonesia hingga saat ini mengalami perkembangan yang signifikan. Hal ini ditandai dengan maraknya kajian-kajian ekonomi syariah, banyaknya lembaga keuangan yang berorientasi syariah serta semakin tingginya kesadaran masyarakat Indonesia dalam menerapkan kerja sama ekonomi berdasarkan syariah seperti perbankan syariah, asuransi syariah, pasar modal syariah dan sebagainya. Khusus pasar modal syariah dikembangkan dalam rangka mengakomodir kebutuhan umat Islam di Indonesia yang ingin melakukan investasi di produk-produk pasar modal yang sesuai dengan prinsip dasar syariah. Dengan semakin beragamnya sarana dan produk investasi di Indonesia, diharapkan masyarakat akan memiliki alternatif berinvestasi yang dianggap sesuai dengan keinginannya, di samping investasi yang selama ini sudah dikenal dan berkembang di sektor perbankan.

Sebagaimana diketahui bahwa Indonesia adalah merupakan sebuah negara dengan penduduk yang mayoritas beragama Islam, oleh karena itu sektor industri pasar modal diharapkan bisa mengakomodir dan sekaligus melibatkan peran serta warga Muslim dimaksud secara langsung untuk ikut aktif menjadi pelaku utama pasar, tentunya adalah sebagai investor lokal di pasar modal Indonesia. Sebagai upaya dalam merealisasikan hal tersebut maka sudah sewajarnya disediakan dan dikembangkan produk-produk investasi di pasar modal Indonesia yang sesuai dengan prinsip dasar ajaran agama Islam. Hal tersebut menjadi penting mengingat masih adanya anggapan dikalangan umat Islam sendiri bahwa berinvestasi di sektor pasar modal di satu sisi merupakan sesuatu yang tidak diperbolehkan (diharamkan) berdasarkan ajaran Islam. Sementara, pada sisi lain bahwa Indonesia juga perlu memperhatikan serta menarik minat investor manca negara untuk berinvestasi di pasar modal Indonesia terutama investor dari negara-negara Timur Tengah yang diyakini merupakan investor potensial.

Dalam ajaran Islam bahwa kegiatan berinvestasi dapat dikategorikan sebagai kegiatan ekonomi yang sekaligus kegiatan tersebut termasuk kegiatan muamalah, yaitu suatu kegiatan yang mengatur hubungan antar manusia. Sementara itu, berdasarkan kaidah bahwa hukum asal dari kegiatan muamalah itu adalah mubah (boleh), yaitu semua kegiatan dalam pola hubungan antar manusia adalah mubah (boleh) kecuali yang jelas ada larangannya (haram). Hal ini berarti ketika suatu kegiatan muamalah yang 
kegiatan tersebut baru muncul dan belum dikenal sebelumnya dalam ajaran Islam maka kegiatan tersebut dianggap dapat diterima kecuali terdapat implikasi dari Al Qur'an dan Hadist yang melarangnya secara implisit maupun eksplisit. Dengan dikembangkannya produk-produk investasi syariah di pasar modal Indonesia, diharapkan bisa mewujudkan pasar modal Indonesia menjadi suatu market yang bisa menarik para investor yang ingin berinvestasi dengan memperhatikan kesesuaian produk dan atau instrumen yang sejalan dengan kaedah-kaedah ajaran Islam. Hal ini tidak hanya terhadap investor lokal, akan tetapi yang tidak kalah pentingnya adalah hal ini diharapkan pula bisa memberikan daya tarik tersendiri terhadap minat investor dari manca negara.

Pandemi COVID-19 membawa dampak terhadap penurunan ekonomi secara global dalam semua jenis usaha perekonomian, termasuk pasar modal. Salah satu dampak COVID-19 yaitu mampu menurunkan harga saham IHSG pada umumnya dan pada semua sektor pasar modal pada khususnya. Dalam masa pengamatan selama Maret 2020, reaksi awal emiten saham syariah pada tanggal 17 Maret 2020 yaitu harga saham serentak menurun di semua sektor bursa efek. Sektor consumer goods industry merupakan sektor yang terbaik dalam menghadapi pandemi COVID-19 hal ini juga didukung dengan jenis bidang usaha tiap emiten yang ada pada sektor ini. Saham sektor mining mampu menjaga kinerja sahamnya, sehingga kepanikan terhadap COVID-19 yang membuat harga saham rendah pada pertengahan Maret hanya terjadi sebentar dan emiten sektor ini dapat dengan mudah menaikkan kembali harga sahamnya. Sedangkan sektor basic industry and chemical, sektor infrastructure, utilities, and transportation, dan sektor miscellaneous industry membutuhkan waktu lebih dari dua minggu untuk bisa kembali menaikkan harga sahamnya.

Dampak ekonomi yang ditimbulkan akibat virus Covid-19 in cukup signifikan, oleh karenanya langkah apa yang paling efektif perlu segera diambil pemerintah agar stabilitas perekonomian Indonesia tetap terjaga. Sehingga ini bisa menjadi peluang sekaligus tantangan bagi pelaku ekonomi khususnya ekonomi syari'ah untuk mengambil peran dalam rangka membantu pemerintah menstabilkan ekonomi. Dalam beberapa literatur Islam klasik memang tidak ditemukan adanya terminologi investasi maupun pasar modal, akan tetapi sebagai suatu kegiatan ekonomi, kegiatan tersebut dapat diketegorikan sebagai kegiatan jual beli (al bay). Oleh karena itu, untuk 
mengetahui peluang dan tantangan kegiatan investasi di pasar modal syariah, sebagai umat Muslim perlu mengetahui hal-hal yang dilarang/diharamkan oleh ajaran Islam dalam hubungan investasi atau perniagaan. Berkaitan uraian tersebut permasalahan yang diangkat dalam artikel ini 1. Bagaimana pemikiran muslim tentang pasar modal syariah? 2. Bagaimana Fatwa Dewan Syariah Nasional yang mengatur tentang kegiatan investasi syariah? 3. Bagaimana tantangan investasi pasar modal syariah di Indonesia ditengah Pandemi Covid-19.

\section{ANALISA DAN PEMBAHASAN 1 \\ Dalil-dalil yang Dapat dijadikan Landasan Pasar Modal Syariah}

Pasar modal syariah dapat diartikan sebagai pasar modal yang menerapkan prinsip-prinsip syariah dalam kegiatan transaksi ekonomi dan terlepas dari hal-hal yang dilarang, seperti: riba, perjudian, spekulasi dan lain-lain. Pasar modal syariah secara resmi diluncurkan pada tanggal 14 Maret 2003 bersamaan dengan penandatanganan MOU antara BAPEPAM-LK dengan Dewan Syariah Nasional - Majelis Ulama Indonesia (DSN - MUI).

Walaupun secara resmi diluncurkan pada tahun 2003, namun instrumen pasar modal syariah telah hadir di Indonesia pada tahun 1997. Hal ini ditandai dengan peluncuran Danareksa Syariah pada 3 Juli 1997 oleh PT Danareksa Investment Management. Selanjutnya Bursa Efek Indonesia berkerjasama dengan PT Danareksa Investment Management meluncurkan Jakarta Islamic Index pada tanggal 3 Juli 2000 yang bertujuan untuk memandu investor yang ingin menanamkan dananya secara syariah. Dengan hadirnya indeks tersebut maka para pemodal telah disediakan sahamsaham yang dapat dijadikan sarana berivestasi dengan penerapan prinsip syariah.

Perkembangan selanjutnya, instrumen investasi syariah di pasar modal terus bertambah dengan kehadiran Obligasi Syariah PT Indosat Tbk pada awal September 2002. Instrumen ini merupakan obligasi syariah pertama dan dilanjutkan dengan penerbitan obligasi syariah lainnya. Pada tahun 2004, terbit untuk pertama kali obligasi syariah dengan akad sewa atau dikenal dengan obligasi syariah Ijarah. Selanjutnya, pada 
tahun 2006 muncul instrumen baru, yaitu reksa dana indeks di mana indeks yang dijadikan sebagai underlying adalah Indeks JII.

Dalam beberapa literatur Islam klasik memang tidak ditemukan adanya terminologi investasi maupun pasar modal, akan tetapi sebagai suatu kegiatan ekonomi, kegiatan tersebut dapat diketegorikan sebagai kegiatan jual beli (al bay). Oleh karena itu, untuk mengetahui apakah kegiatan investasi di pasar modal merupakan sesuatu yang dibolehkan atau tidak menurut ajaran Islam maka perlu diketahui hal-hal yang dilarang/diharamkan oleh ajaran Islam dalam hubungan jual beli.

Konsep dasar investasi syariah di pasar modal Indonesia apabila dilihat dalam AlQur'an dan Hadist sebagai sumber utama ajaran Islam maka dapat dilihat beberapa ketentuan mengenai hal tersebut:

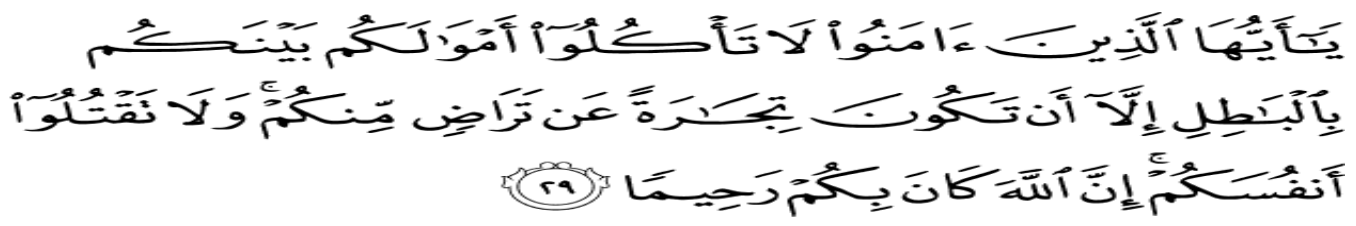

"Hai orang-orang yang beriman, janganlah kamu saling memakan harta sesamamu dengan jalan yang batil, kecuali dengan jalan perniagaan yang berlaku dengan suka sama-suka di antara kamu...".

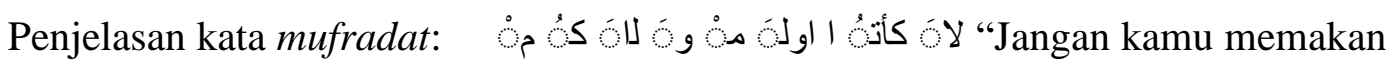
harta-harta kamu". Adapun yang dimaksud "makan" adalah segala bentuk tindakan, baik mengambil atau menguasai. Harta-harta kamu, meliputi seluruh jenis harta, semuanya termasuk kecuali bila ada dalil syar'i yang menunjukkan kebolehannya. Meskipun yang disebutkan di sini hanya "makan", tetapi yang dimaksud adalah segala bentuk transaksi, baik penggunaan maupun pemanfaatan.

Kata amwalakum yang dimaksud adalah harta yang beredar dalam masyarakat. ${ }^{2}$ Amwalakum (harta kamu) adalah baik yang ditanganmu sendiri maupun yang ditangan orang lain. Lalu harta kamu itu, dengan takdir dan karunia Allah Swt ada yang diserahkan ketanganmu dan ada pula yang diserahkan ke tangan

${ }^{1}$ Q.S. (4) : 29.

${ }^{2}$ M. Quraish Shihab, Tafsir Al-Misbah: Pesan, Kesan, dan Keserasian Al-Qur'an, Jakarta, Lentera Hati, 2002, HIm. 412. 
kawanmu yang lain. Oleh karena itu, betapapun kayanya seseorang janganlah sekali-kali ia lupa bahwa pada hakikatnya kekayaan itu adalah kepunyaan bersama juga. $^{3}$

بـ "Dengan cara yang batil”, yaitu segala perkara yang diharamkan Allah SWT atau tidak ada haknya. Bathil, yakni pelanggaran terhadap ketentuan agama atau persyaratan yang disepakati. Dalam konteks ini Nabi Saw bersabda, "kaum Muslimin sesuai dengan (harus menepati) syaratsyarat yang mereka sepakati, selama tidak menghalalkan yang haram atau mengharamkan yang halal". ${ }^{4}$

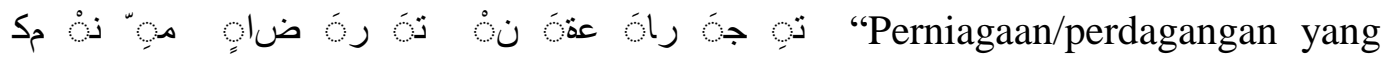
berdasarkan kerelaan di antara kamu". Ayat ini dengan tegas melarang orang memakan harta orang lain atau hartanya sendiri dengan jalan bathil. Memakan harta sendiri dengan jalan bathil adalah membelanjakan hartanya pada jalan maksiat. Memakan harta orang lain dengan cara bathil ada berbagai caranya, seperti pendapat Suddi memakannya dengan jalan riba, judi, menipu, menganiaya. Termasuk juga dalam jalan yang batal ini segala jual beli yang dilarang syara. ${ }^{5}$

Kata perniagaan yang berasal dari kata niaga, yang kadang-kadang disebut pula dagang atau perdagangan amat luas maksudnya, segala jual beli, sewa menyewa, impor dan ekspor, upah mengupah, dan semua yang menimbulkan peredaran harta benda termasuklah itu dalam bidang niaga. ${ }^{6}$

Ayat 29 dari surat An-Nisa di atas penulis paparkan pertama karena ayat tersebut berkaitan dengan prinsip mudharabah yang merupakan salah satu akad utama dalam sistem pasar modal syariah. Pembiayaan mudharabah adalah pembiayaan yang disalurkan oleh Lembaga Keuangan Syariah (LKS) kepada pihak lain untuk suatu usaha yang produktif.

Akad mudharabah, yaitu akad kerja sama suatu usaha antara dua pihak di mana pihak pertama (malik, shahib al-mal, LKS) menyediakan seluruh modal,

${ }^{3}$ Hamka, Tafsir Al-Azhar Juz V, Jakarta, Pustaka Panjimas, 1983, HIm. 35.

${ }^{4}$ M. Quraish Shihab, Tafsir A/-Misbah...Op.Cit., HIm. 413.

${ }^{5}$ Syekh. H. Abdul Halim Hasan Binjai, Tafsir Al-Ahkam, Jakarta, Kencana, 2006, HIm. 258.

${ }^{6}$ Hamka, Tafsir Al-Azhar...Op.Cit., HIm. 36.

${ }^{7}$ Lihat Fatwa Dewan Syari'ah Nasional No: 07/DSN-MUI/IV/2000 tentang Pembiayaan Mudharabah (Qiradh). 
sedangkan pihak kedua (amil, mudharib, nasabah) bertindak selaku pengelola, dan keuntungan usaha dibagi di antara mereka sesuai kesepakatan yang dituangkan dalam kontrak. Dalam pembiayaan ini LKS sebagai shahibul maal (pemilik dana) membiayai $100 \%$ kebutuhan suatu proyek (usaha), sedangkan pengusaha (nasabah) bertindak sebagai mudharib atau pengelola usaha. Jangka waktu usaha, tata cara pengembalian dana, dan pembagian keuntungan ditentukan berdasarkan kesepakatan kedua belah pihak (LKS dengan pengusaha). ${ }^{8}$

Jika sudah terjadi kesepakatan antara LKS dengan pengusaha untuk pengelolaan modal yang diberikan oleh LKS kepada pengusaha maka keduanya wajib memenuhi akad itu, harus amanat, tidak saling merugikan, tidak saling mendzalimi, dan kedua belah pihak harus saling ridho, artinya tidak ada paksaan sama sekali, sebagaimana tersurat dalam ayat di atas. Berikut adalah ayat pendukungnya, mari dicermati firman Allah Swt berikut ini: ${ }^{9}$

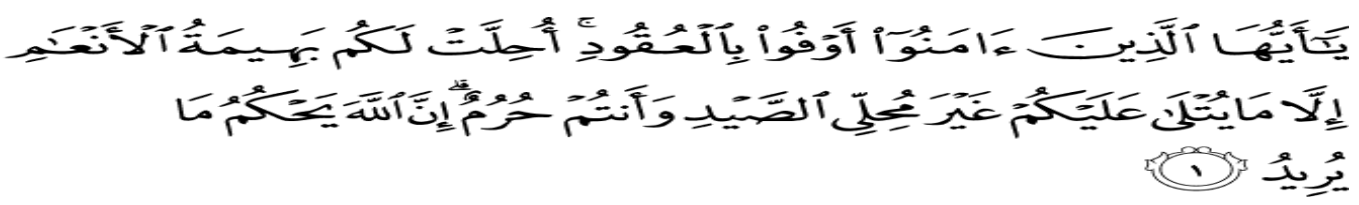

Hai orang yang beriman! Penuhilah akad-akad itu...”.

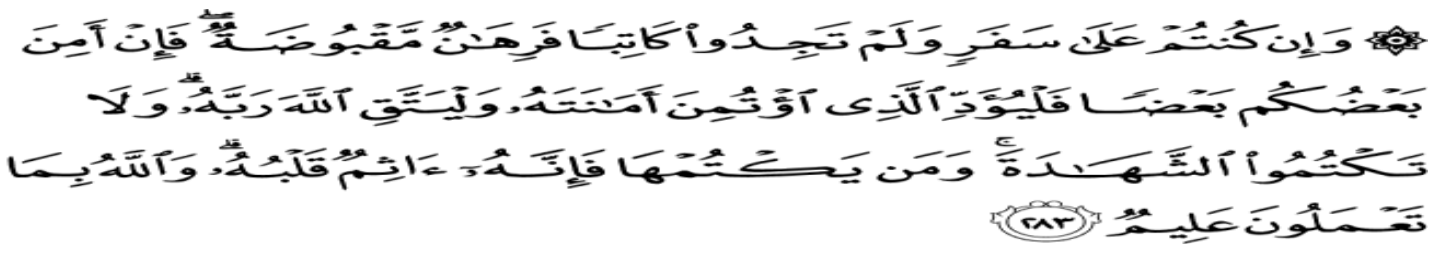

“...Maka, jika sebagian kamu mempercayai sebagian yang lain, hendaklah yang dipercayai itu menunaikan amanatnya dan hendaklah ia bertakwa kepada Allah Tuhannya..."10

${ }^{8}$ Ibid.

${ }^{9}$ Q.S. (5) : 1.

${ }^{10}$ Q.S. (2) : 283. 


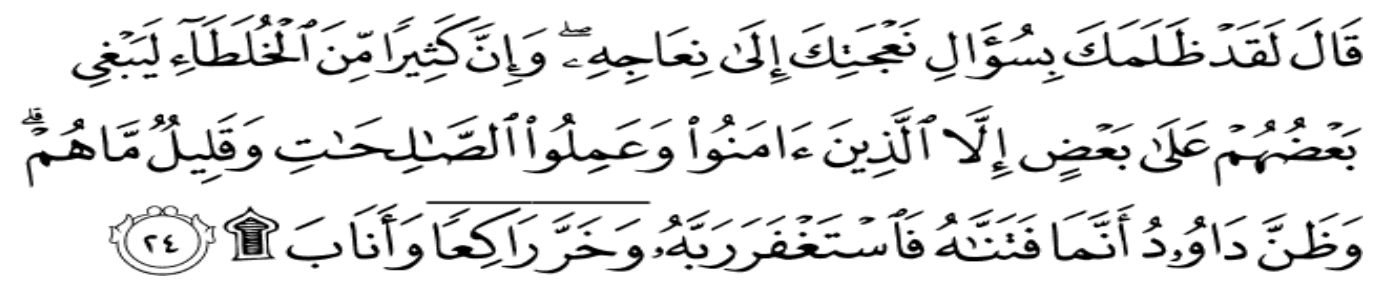

“...Dan sesungguhnya kebanyakan dari orang-orang yang bersyarikat itu sebagian dari mereka berbuat zalim kepada sebagian lain, kecuali orang yang beriman dan mengerjakan amal shaleh; dan amat sedikitlah mereka ini...". ${ }^{11}$

"Sesungguhnya kebanyakan dari orang-orang yang berserikat itu", yakni orang-orang yang terlibat dalam satu perserikatan. Kebutuhan masyarakat untuk meningkatkan kesejahteraan dan usaha terkadang memerlukan dana dari pihak lain, antara lain melalui pembiayaan musyarakah, yaitu pembiayaan berdasarkan akad kerja sama antara dua pihak atau lebih untuk suatu usaha tertentu, di mana masing-masing pihak memberikan kontribusi dana dengan ketentuan bahwa keuntungan dan risiko akan ditanggung bersama sesuai dengan kesepakatan.

Pembiayaan musyarakah memiliki keunggulan dalam kebersamaan dan keadilan, baik dalam berbagi keuntungan maupun resiko kerugian. Oleh karena itu, akad musyarakah merupakan akad yang bagus digunakan dalam sistem pasar modal syariah yang dikelola oleh Lembaga Keuangan Syariah (LKS). Mari cermati Hadits Rasulullah saw tentang syirkah. Hadits riwayat Abu Daud dari Abu Hurairah, Rasulullah Saw berkata:

"Allah Swt, berfirman: Aku adalah pihak ketiga dari dua orang yang bersyarikat selama salah satu pihak tidak mengkhianati pihak yang lain. Jika salah satu pihak telah berkhianat, Aku keluar dari mereka”. (HR. Abu Daud, yang dishahihkan oleh al-Hakim, dari Abu Hurairah).

Berdasarkan Al-Qur'an, Hadist di atas maka sesuatu yang dilarang atau diharamkan:

1. Haram karena bendanya (zatnya). Pelarangan kegiatan muamalah ini disebabkan karena benda atau zat yang menjadi objek dari kegiatan tersebut

${ }^{11}$ Q.S. (38) : 24. 
berdasarkan ketentuan al Qur'an dan Hadist telah dilarang/ diharamkan. Benda-benda tersebut, antara lain: babi, khamr (minuman keras), bangkai binatang, dan darah.

2. Haram selain karena bendanya (zatnya). Pengertian dari pelarangan atas kegiatan ini adalah suatu kegiatan yang objek dari kegiatan tersebut bukan merupakan benda-benda yang diharamkan karena zatnya artinya benda-benda tersebut benda-benda yang dibolehkan (dihalalkan). Akan tetapi, benda tersebut menjadi diharamkan disebabkan adanya unsur: tadlis, taghrir/ gharar, riba. Terjadinya: ikhtikar dan bay najash. Tidak sahnya akadnya, seperti halnya dengan pengharaman disebabkan karena selain zatnya maka pada kegiatan ini benda yang dijadikan objeknya adalah benda yang berdasarkan zatnya dikategorikan halal (dibolehkan), tetapi benda tersebut menjadi haram disebabkan akad atau penjanjian yang menjadikan dasar atas transaksi tersebut dilarang/diharamkan oleh ajaran Islam. Perjanjianperjanjian tersebut, antara lain: ta'aluq, terjadi suatu perjanjian di mana pelaku, objek dan periodenya sama.

\section{Tafsir Maudhu'i Tentang Beberapa Efek Pasar Modal Syariah}

Kata maudhu" $i$ berasal dari bahasa Arab, yaitu maudhu yang merupakan isim maf"ul dari fi"il madhi wadha"a yang berarti meletakkan, menjadikan, mendustakan dan membuat-buat. Arti maudhu" $i$ yang dimaksud adalah yang dibicarakan atau judul atau topik atau sektor, sehingga tafsir maudhu" $i$ berarti penjelasan ayat-ayat Alquran yang mengenai satu judul, topik atau sektor pembicaraan tertentu. Maudhu" $i$ yang berarti yang didustakan atau dibuat-buat, ${ }^{12}$ seperti arti kata Hadist maudhu yang berarti Hadist yang didustakan, dipalsukan ataupun dibuat-buat.

Adapun pengertian tafsir maudhu"i secara tematik adalah mengumpulkan ayat-ayat al-Qurean yang mempunyai tujuan yang satu yang bersama-sama membahas judul, topik atau sektor tertentu dan menertibkannya sebagaimana mungkin $83-4$.

${ }^{12}$ Abdul Djalal, Urgensi Tafsir Maudlin'i Pada Masa Kini, Kalam Mulia, Jakarta, 1990, Hlm. 
masa turunnya selaras dengan sebab-sebab turunnya, kemudian memperhatikan ayat -ayat tersebut dengan penjelasan-penjelasan, keterangan-keterangan dan hubungan-hubungannya dengan ayat-ayat lain, kemudian menyimpulkan hukumhukumnya.

Berikut dipaparkan beberapa produk pasar modal syariah menggunakan metode maudhu" $i$ :

\section{Reksa dana syariah}

Reksa dana syariah adalah wadah yang dipergunakan untuk menghimpun dana dari masyarakat pemodal sebagai pemilik harta (shabib al-mal/rabb al-mal) untuk selanjutnya diinvestasikan dalam portofolio efek oleh Manajer Investasi sebagai wakil shahib al-mal menurut ketentuan dan prinsip Syariah Islam, sedangkan porto folio efek adalah kumpulan efek yang dimiliki secara bersama (kolektif) oleh para pemodal dalam reksa dana.

Reksa dana syariah halal selama dalam pelaksaannya tidak ada unsur yang dilarang seperti riba, dzalim, dan transaksinya harus dengan prinsip saling ridho. Firman Allah Swt: ${ }^{13}$

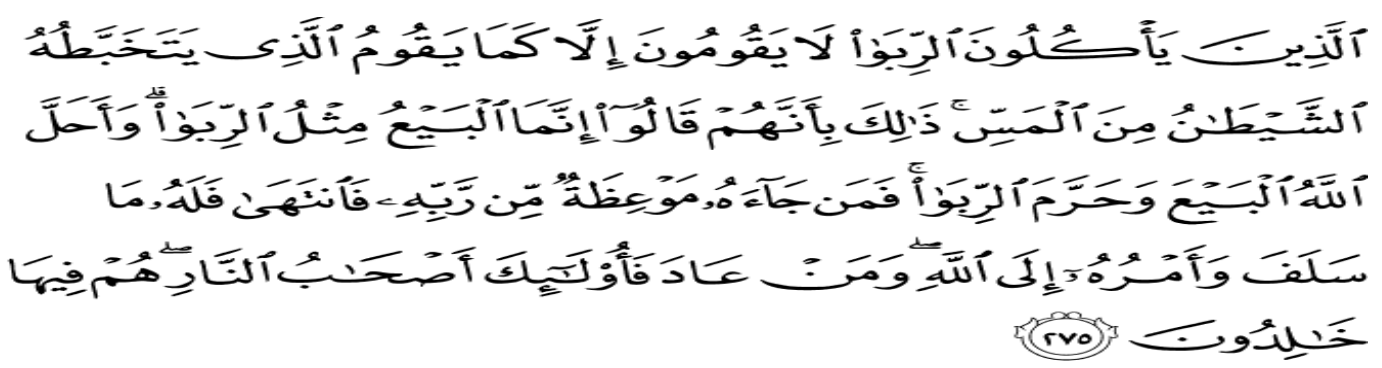

“...dan Allah menghalalkan jual beli dan mengharamkan riba...”.

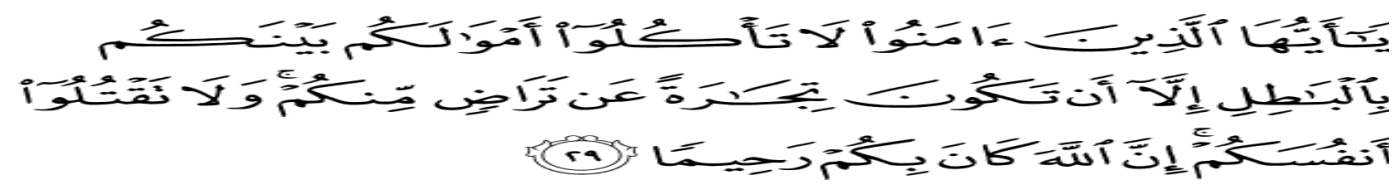

${ }^{13}$ Q.S. (2) : 275. 
"Hai orang-orang yang beriman, janganlah kamu saling memakan harta sesamamu dengan jalan yang batil, kecuali dengan jalan perniagaan yang berlaku dengan suka sama-suka di antara kamu...". ${ }^{14}$

Kedua belah pihak yang bersepakat dalam transaksi reksa dana syariah ini harus bersifat amanah, jujur dan tanggung jawab. Investasi dalam bentuk reksa dana syariah ini baiknya diniatkan untuk mengamalkan perintah Allah Swt untuk mencari karunia-NYA di muka bumi ini. Firman Allah Swt: ${ }^{15}$

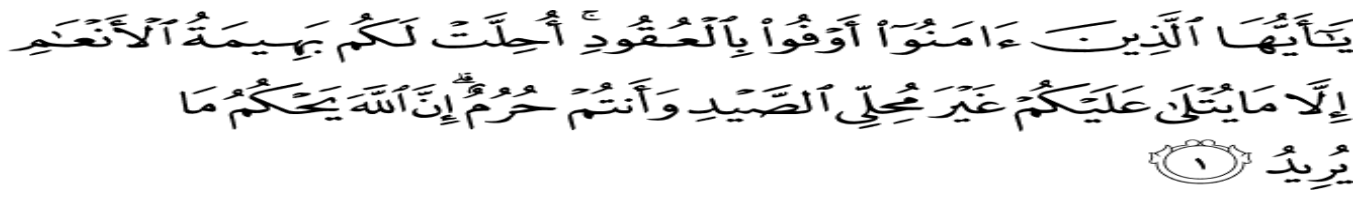

"Hai orang yang beriman! Penuhilah akad-akad itu..."

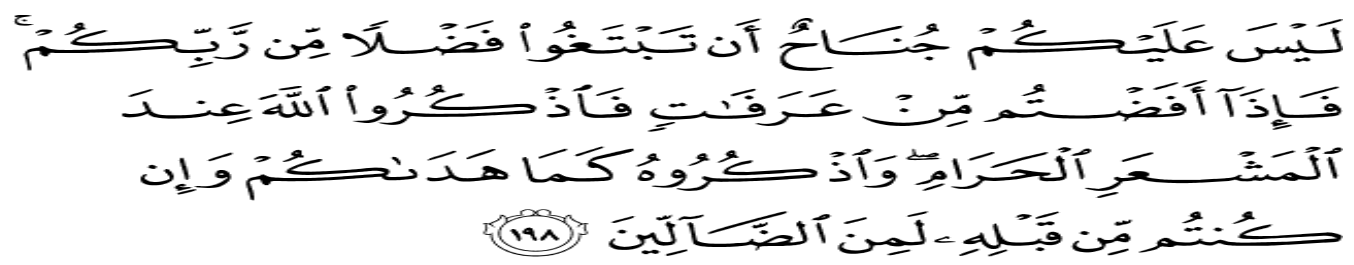

Tidak ada dosa bagimu untuk mencari karunia dari Tuhanmu...". 16

Juga dalam melakukan transaksi reksa dana syariah tidak diperbolehkan melakukan tindakan spekulasi, yang didalamnya mengandung gharar, seperti penawaran palsu dan tindakan spekulasi lainnya. Tidak boleh dalam poin-poin perjanjiannya mencantumkan hal-hal yang diharamkan oleh Allah Swt. Hadits Rasulullah Saw:

"Perdamaian dapat dilakukan di antara kaum muslimin kecuali perdamaian yang mengharamkan yang halal atau menghalalkan yang haram; dan kaum muslimin terikat dengan syarat-syarat mereka kecuali syarat yang mengharamkan yang halal atau menghalalkan yang haram”. (HR. Tirmizi dari “Amr bin 'Auf)

\section{Obligasi syariah}

${ }^{14}$ Q.S. (4) : 29.

${ }^{15}$ Q.S. (5) : 1.

${ }^{16}$ Q.S. (2) : 198. 
Salah satu bentuk instrumen investasi pada pasar modal (konvensional) adalah obligasi yang selama ini didefinisikan sebagai suatu surat berharga jangka panjang yang bersifat utang yang dikeluarkan oleh emiten kepada pemegang obligasi dengan kewajiban membayar bunga pada periode tertentu dan melunasi pokok pada saat jatuh tempo kepada pemegang obligasi.

Obligasi sebagaimana pengertian di atas, yang telah diterbitkan selama ini masih belum sesuai dengan ketentuan syariah sehingga belum dapat mengakomodir kebutuhan masyarakat akan obligasi yang sesuai dengan syariah. Namun, obligasi itu bisa diterbitkan sesuai prinsip syariah.

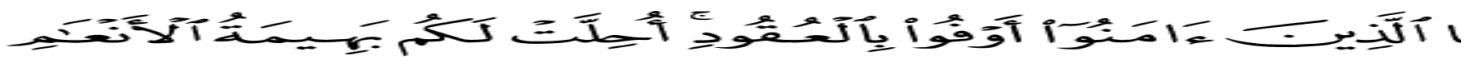

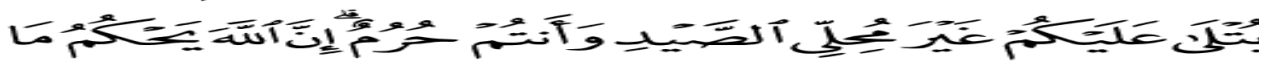
S?

"Hai orang yang beriman! Penuhilah akad-akad itu..."17

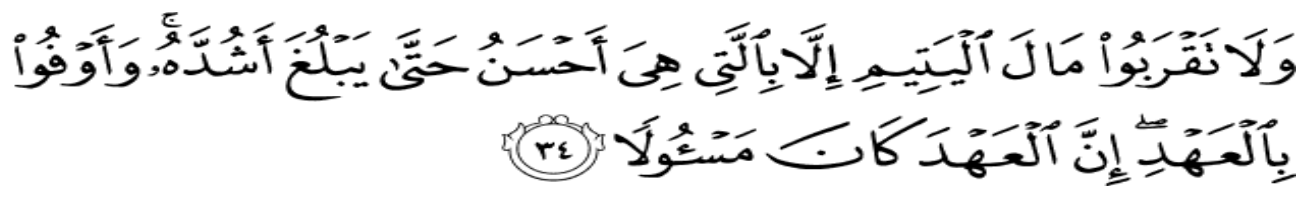

“...dan penuhilah janji; sesungguhnya janji itu pasti diminta pertanggunganjawabnya”. ${ }^{18}$

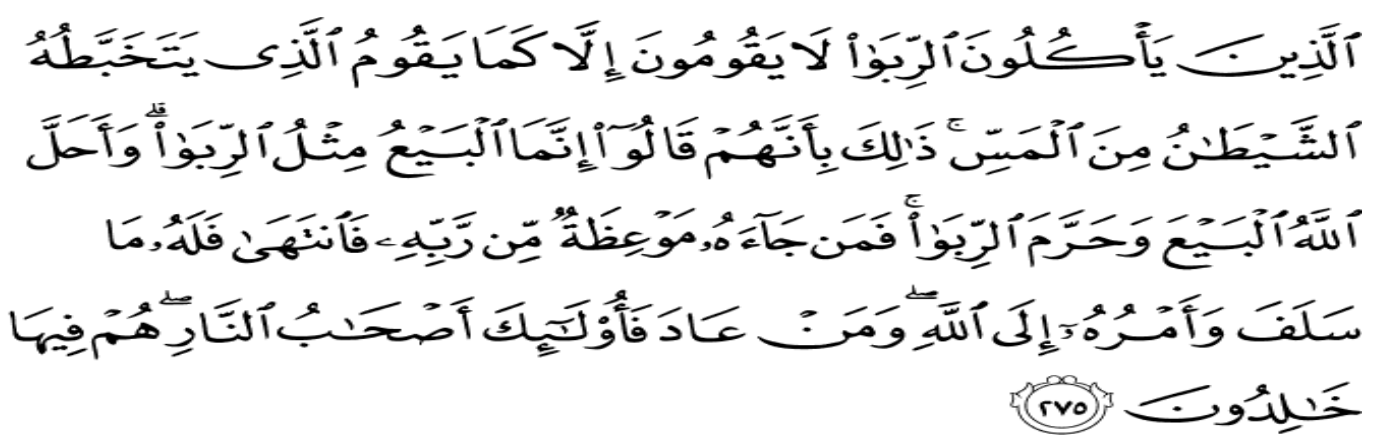

"Orang yang makan (mengambil) riba tidak dapat berdiri melainkan seperti berdirinya orang yang kemasukan syaitan lantaran (tekanan) penyakit gila.

${ }^{17}$ Q.S. (5) : 1.

${ }^{18}$ Q.S. (17) : 34. 
Keadaan mereka yang demikian itu adalah disebabkan mereka berkata (berpendapat), sesungguhnya jual beli itu sama dengan riba, padahal Allah telah menghalalkan jual beli dan mengharamkan riba. Orang yang telah sampai kepadanya larangan dari Tuhannya, lalu terus berhenti (dari mengambil riba) maka baginya apa yang telah diambilnya dahulu (sebelum datang larangan); dan urusannya (terserah) kepada Allah. Orang yang mengulangi (mengambil riba) maka orang itu adalah penghuni-penghuni neraka; mereka kekal didalamnya". ${ }^{19}$

Hadits Rasulullah Saw:

"Perdamaian dapat dilakukan di antara kaum muslimin kecuali perdamaian yang mengharamkan yang halal atau menghalalkan yang haram; dan kaum muslimin terikat dengan syarat-syarat mereka kecuali syarat yang mengharamkan yang halal atau menghalalkan yang haram”. (HR. Tirmizi dari 'Amr bin 'Auf).

\section{Surat berharga syariah negara}

Surat Berharga Syariah Negara (SBSN) atau dapat juga disebut Sukuk Negara adalah merupakan surat berharga (obligasi) yang diterbitkan oleh pemerintah Republik Indonesia berdasarkan prinsip syariah. Perusahaan yang akan menerbitkan SBSN ini adalah merupakan perusahaan yang secara khusus dibentuk guna kepentingan penerbitan SBSN ini (special purpose vehicle-SPV). ${ }^{20}$

BSN atau sukuk negara ini adalah merupakan suatu instrumen utang piutang tanpa riba sebagaimana dalam obligasi, di mana sukuk ini diterbitkan berdasarkan suatu aset acuan yang sesuai dengan prinsip syariah. ${ }^{21}$ Sesuai dengan Undang-Undang Nomor 19 Tahun 2008 tentang Surat Berharga Syariah Negara (SBSN), Pemerintah dapat menerbitkan surat berharga berbasis syariah dalam rangka menunjang kesinambungan fiskal dan memperluas sumber pembiayaan negara. ${ }^{22}$

Firman Allah Swt: ${ }^{23}$

\footnotetext{
${ }^{19}$ Q.S. (2) : 275.

${ }^{20}$ http://id.wikipedia.org/wiki/Surat_Berharga_Syariah_Negara, terakhir kali diakses 11 Juni 2015.

${ }^{21}$ Ibid.

${ }^{22}$ Lihat Fatwa Dewan Syari'ah Nasional No: 69/DSN-MUI/VI/2008 tentang Surat Berharga Syariah Negara.

${ }^{23}$ Q.S. (4) : 29.
} 
"Hai orang-orang yang beriman, janganlah kamu saling memakan harta sesamamu dengan jalan yang batil, kecuali dengan jalan perniagaan yang berlaku dengan suka sama-suka di antara kamu...”.

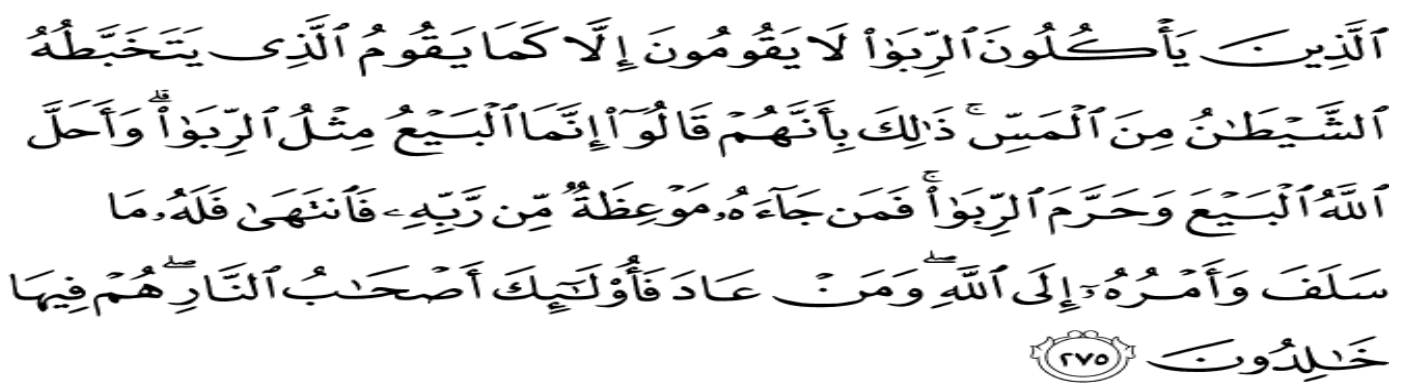

“Orang yang makan (mengambil) riba tidak dapat berdiri melainkan seperti berdirinya orang yang kemasukan syaitan lantaran (tekanan) penyakit gila. Keadaan mereka yang demikian itu adalah disebabkan mereka berkata (berpendapat), sesungguhnya jual beli itu sama dengan riba, padahal Allah telah menghalalkan jual beli dan mengharamkan riba. Orang yang telah sampai kepadanya larangan dari Tuhannya, lalu terus berhenti (dari mengambil riba) maka baginya apa yang telah diambilnya dahulu (sebelum datang larangan); dan urusannya (terserah) kepada Allah. Orang yang mengulangi (mengambil riba) maka orang itu adalah penghuni-penghuni neraka; mereka kekal di dalamnya".24

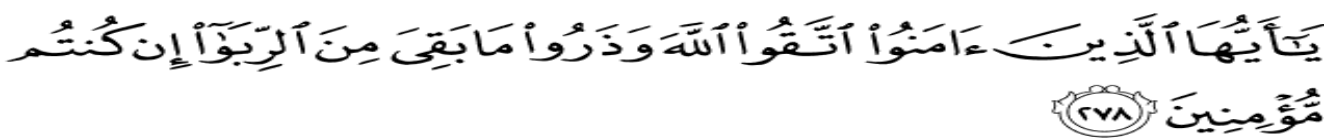

"Hai orang yang beriman, bertakwalah kepada Allah dan tinggalkan sisa riba (yang belum dipungut) jika kamu orang-orang yang beriman". 25

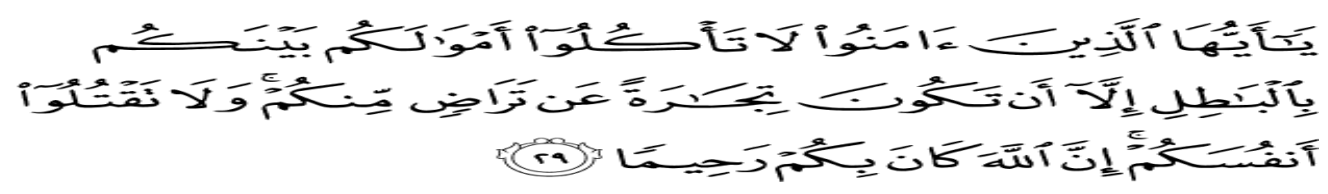

"Hai orang-orang yang beriman, janganlah kamu saling memakan harta sesamamu dengan jalan yang batil, kecuali dengan jalan perniagaan yang berlaku dengan suka sama-suka di antara kamu...". ${ }^{26}$

${ }^{24}$ Q.S. (2) : 275.

${ }^{25}$ Q.S. (2) : 278.

${ }^{26}$ Q.S. (4) : 29. 


\section{Pemikiran Muslim Tentang Pasar Modal Syariah}

Pasar modal jelas tidak dikenal pada masa Rasulullah Saw dan para sahabat. Kegiatan ekonomi pada masa itu adalah transaksi pada sektor riil saja. Keikutsertaan modal dalam bentuk kepemilikan suatu perusahaan (syirkah) tidak ditunjukkan dalam bentuk kepemilikan saham seperti saat ini. Dengan demikian, transaksi yang terjadi hanya dalam bentuk transaksi jual beli biasa dengan menggunakan uang atau dengan cara pertukaran antar barang melalui barter.

Sistem ekonomi Islam didasarkan pada transaksi asset riil yang produktif pada sektor riil. ${ }^{27}$ Olehnya, pasar modal syariah juga harus didasarkan pada pasar sekuritas berbasis ekuitas, bukan berbasis pada utang. Model pasar modal syariah yang memenuhi prinsip syariah Islam belum diformulasikan secara formal. Namun, perlu diidentifikasi beberapa isu penting sehingga dapat dibedakan pasar modal syariah dengan pasar modal konvensional.

Menurut Iqbal dan Mirakhor, setidaknya tiga hal penting yang harus diperhatikan. ${ }^{28}$ Pertama, mengenai perjanjian kontraktual yang dapat merepresentasikan dengan tepat bagian dalam perusahaan saham gabungan dengan liabilitas (utang) terbatas. Hal ini menjadi penting terutama terkait dengan legalitas entitas korporasi dan perlakuannya sebagai judicial person, terutama jika terjadi kasus gagal bayar perusahaan atas liabilitas/kewajibannya. Kedua, mengenai jenis kontrak yang sesuai untuk saham biasa sebagai mitra dalam saham perusahaan, berdasarkan musyarakah mulk atau musyarakah aqed. ${ }^{29}$ Pengklasifikasian saham perusahaan dalam kontrak musyarakah mulk menyebabkan sebagian besar transaksi saham di pasar modal tidak bisa diterima secara syariah. ${ }^{30}$ Negotiability, transferability dan tradability di pasar primer dan sekunder menjadi isu penting ketiga yang perlu dicermati. Sebagaimana

\footnotetext{
${ }^{27}$ Menurut Chapra (2008), Chapra, Ebrahim, Mirakhor, dan Siddiqi (2008), transaksi jatas asset/harta riil adalah salah satu dari empat kondisi fundamental dari keuangan Islam yang dapat menekan kelebihan utang (leverage) dan spekulasi di pasar modal, lebih lanjut lihat Amelie Charles, Olivier Darne, Adrian POP, "Is the Islamic Finance Model More Resilient the Conventional Finance Model? Evidence from Sudden Changes in the Dow Jones Indexes", jurnal SSRN, http://ssrn.com/abstract=18367651, diakses tanggal 15 Februari 2015.

${ }^{28}$ Zamir Iqbal dan Abbas Mirakhor, Pengantar Keuangan Islam: Teori dan Praktik, Jakarta, Kencana, 2008, HIm. 220-223.

${ }^{29}$ Ibid.

${ }^{30}$ Ibid.
} 
disebutkan bahwa ekonomi Islam mendorong transaksi atas aset/barang riil (tangible), yang berarti pelarangan terhadap transaksi utang (dayn), mata uang, obligasi yang dibatasi dalam barang generik, serta hak kontinjen (seperti options, futures, forward), di mana instrumen-instrumen ini ditransaksikan di pasar modal.

Perbedaan mendasar antara pasar modal syariah dan pasar modal konvensional adalah bahwa pelaksanaan pasar modal syariah secara umum tidak hanya ditentukan oleh kondisi bisnis, lingkungan sosial ekonomi, dan politik. Terdapat prinsip penting mengenai apa yang benar dan apa yang tidak benar yang didasarkan pada al-Quran dan Hadist Rasulullah Saw. Prinsip yang dimaksud adalah pelarangan riba, spekulasi serta serangkaian kegiatan yang dilarang, yaitu ketidakpastian (gharar), judi (maysir), ketidaktahuan $(j a h l) .{ }^{3 l}$ Prinsip-prinsip tersebut harus dipedomani dalam semua transaksi ekonomi, termasuk pasar modal. ${ }^{32}$

Dewan Syariah Nasional (DSN)-MUI Indonesia memastikan bahwa kegiatan transaksi dan investasi di pasar modal syariah Indonesia tidak melibatkan unsur-unsur tersebut. Hal ini berlaku baik untuk instrumen ekuitas (saham) maupun utang (obligasi) serta derivatif (instrumen turunan) dari saham. Beberapa fatwa telah dikeluarkan oleh DSN-MUI (Dewan Syariah Nasional-Majelis Ulama Indonesia) terkait dengan transaksi dan instrumen pasar modal yang memenuhi prinsip syariah. Salah satu diantaranya adalah fatwa Nomor 65/DSN_MUI/III/2008 mengenai Hak Memesan Efek Terlebih Dahulu (HMETD) atau right issue. ${ }^{33}$

Fatwa ini memastikan kehalalan investasi pada instrumen saham dan juga pada produk turunan (derivatif), yaitu instrumen yang berbentuk rights (hak) yang melekat pada produk induknya (underlying asset). Hak ini merupakan salah satu produk pasar modal yang bersifat utang, yang dalam prinsip ekonomi Islam tidak diakomodasi.

Menurut Ushaimi, dari aspek hukum beberapa ekonom Muslim (fuqaha) memiliki pendapat yang berbeda dalam menilai apakah transaksi sekuritas dalam pasar

${ }^{32}$ Obiyathullah Ismath Bacha, Derivative Instruments and Islamic Finance: Some Thoughts for $A$ Reconsideration, International Journal of Islamic Financial Services, Volume 1, Nomor 1, 1999, HIm. 8.

${ }^{33}$ Andri Soemitra, Bank dan Lembaga Keuangan Syariah, Edisi Pertama, Jakarta, Kencana, 2009, HIm. 153. Beberapa fatwa yang terkait dengan pengembangan pasar modal syariah di Indonesia, telah dikeluarkan oleh DSN-MUI, lihat Burhanuddin Susanto, Pasar Modal Syariah: Tinjauan Hukum, Yogyakarta, UII Press, 2009, HIm. 12. 
modal syariah mengandung unsur-unsur yang dilarang secara syariah. Beberapa alasan tidak diperbolehkannya transaksi (saham) di pasar modal: ${ }^{34}$

"Pertama, saham merupakan instrumen yang sama dengan obligasi (yang merepresentasikan utang), karena perusahaan berutang pada investor yang suatu saat harus dikembalikan. Bertransaksi saham sama hukumnya dengan bertransaksi utang yang secara syariah dilarang. Kedua, riba najsy masih banyak terjadi dalam kegiatan transaksi di pasar modal. Ketiga, mobilitas (keluar-masuknya) investor di pasar modal tidak diketahui oleh seluruh pemegang saham. Keempat, adanya percampuran antara harta dan modal perusahaan dengan yang mengandung unsur haram maka semuanya haram. Kelima, harga saham tidak mencerminkan modal awal pada waktu pendirian perusahaan, tetapi ditentukan pada saat awal penerbitannya $(I P O=$ Initial Public Offering $)$. Keenam, transaksi saham tidak memenuhi unsur penyerahan (taqabudh) dan persamaan nilai (tamatsul), yang seharusnya ada dalam kegiatan pertukaran jual beli. Ketujuh, investor tidak mengetahui secara pasti spesifikasi barang yang dibelinya yang direpresentasikan dalam bentuk saham".

Dengan kata lain, terdapat unsur ketidaktahuan (jahl) dalam transaksi saham, sehingga transaksinya batal karena salah satu syarat sahnya jual beli adalah bahwa pembeli tahu barang yang hendak dibelinya. Selain itu, harga saham berfluktuasi sesuai kondisi pasar saham, sehingga saham tidak merupakan pembayaran nilai yang sama pada saat perusahaan didirikan (at parvalue). Selain itu praktik short-selling (menjual saham yang belum dimiliki oleh penjual) yang dilakukan oleh investor, sangat tidak sesuai dengan prinsip Islam.

Para ekonom Islam memiliki pendapat yang berbeda pula terkait produk forward dan futures $^{35}$ yang juga diperdagangkan di pasar modal. Mohammad Obaidullah dan Hakim Muhammad Taqi Uthmani menyatakan bahwa "perdagangan forward dan futures ini melanggar aturan hukum Islam karena transaksi keduanya hanya perjanjian untuk menyerahkan sejumlah dana dan barang di masa yang akan datang, penyerahan

\footnotetext{
${ }^{34}$ Saptono Budi Satrio, Optimasi Portofolio Saham Syariah (Studi Kasus Bursa Efek Jakarta Tahun 2002-2004), Tesis Program Pascasarjana PSKTTI-UI Jakarta, 2005.

${ }^{35}$ Nurul Huda dan Mustafa Edwin Nasution, Investasi pada Pasar Modal Syariah, Jakarta, Kencana, 2007, HIm. 64-65.
} 
barang yang ditransaksikan umumnya tidak dilakukan dan ketika transaksi berakhir yang terjadi hanyalah penetapan perbedaan harga". 36

Jadi, sebagian besar transaksi futures itu hanya bersifat spekulasi (maysir) di masa yang akan datang. Lebih jauh, tujuan penggunaan transaksi futures dan forward yang bertujuan untuk menghindari (hedge out) ketidakpastian bisnis di masa depan tidak memiliki pengaruh, karena hal ini menurut, Uthmani tidak diperbolehkan dalam syariah. Abdul Rahim al-Saati juga memiliki argumentasi yang sama dan bahkan menyatakan bahwa ekonom muslim lainnya seperti: Umer Chapra (1992), M. Fahim Khan (1995), M. Akram Khan (1988), A. Muhiaddin (1995), A.Y. Sulayman (1982), Subhi Mahmassani (1983) and Majma'al Fiqh al-Islami (1989) juga menolak kontrak futures. $^{37}$

Obaidullah juga mendukung pendapat Uthmani dengan menyatakan bahwa transaksi seperti itu adalah transaksi utang (bai'-al dayn-bi-al-dayn), transaksi yang dilarang dalam syariah, terlebih transaksi futures terhadap komoditas yang tidak dimiliki (short-selling) penjual menimbulkan unsur gharar. Umumnya futures dan forward (terutama untuk transaksi kurs mata uang) digunakan untuk spekulasi, yang justru akan makin meningkatkan volatilitas nilai kurs mata uang dan akhirnya akan menimbulkan skala ekonomi yang besar. Argumentasi ini merupakan alasan rasional ekonomi tidak dibolehkannya upaya hedging menggunakan futures dan forward dalam syariah. ${ }^{38}$

Namun, beberapa ekonom Muslim, membolehkan keberadaan kontrak futures dan forward, seperti Ali Salehabadi dan Mohammad Aram, Muhammed Sahid Ebrahim serta Mohammad Hashim Kamali. Dua ekonom Iran, Ali Salehabadi dan Mohammad Aram, menyatakan bahwa "penggunaan kontrak futures untuk

\footnotetext{
${ }^{36}$ Transaksi berjangka komoditas (dapat berupa hasil pertanian, hasil tambang), dan juga berupa nilai mata uang, di mana penyerahan barang yang diperjanjikan saat ini diserahkan pada suatu periode waktu tertentu di masa depan, dengan nilai yang telah disepakati pada saat kedua belah pihak memasuki kontrak (predetermined price).

${ }^{37}$ Mohammed Obaidullah, Islamic Financial Services, Jeddah, Saudi Arabia, Islamic Economic Research Centre, King Abdulaziz University, 2005, dalam Salmah Said, Pemikiran Ekonom Muslim Tentang Pasar Modal Syariah, Jurnal Al-Fikr, Volume 16 Nomor 2 Tahun 2012, Hlm. 7.

${ }^{38} \mathrm{Hal}$ ini dikenal sebagai marking-to-market atau daily settlement dalam pasar futures dan forward. Kegiatan ini dilakukan di akhir perdagangan setiap hari untuk menyeimbangkan posisi semua futures dan ditulis kembali dalam bentuk penetapan harga pada hari tersebut oleh pihak bursa (clearing house)
} 
mengantisipasi risiko berfluktuasinya harga (dalam hal ini harga minyak mentah, di mana Iran salah satu negara produsen minyak mentah) dapat diterima". ${ }^{39}$ Negara produsen minyak mentah akan memperoleh keuntungan dengan kontrak futures dari pada menjualnya di pasar spot. Tanpa mengabaikan pendapat ekonom Muslim lainnya, alasan yang dikemukakan keduanya adalah bahwa kontrak futures dipandang sebagai kontrak yang masih berlanjut di masa depan (undetermined concluding contract) karena adanya kewajiban pada perdagangan di masa depan yang akan efektif di periode tertentu di masa depan, sehingga berbeda dengan konsep jual beli.

Menurut Salehabadi dan Aram, kontrak futures adalah bentuk kontrak joalah, ${ }^{40}$ dan karenanya dapat diterima sesuai dengan prinsip Islam. Menurut Muhammad Sahid Ebrahim mengutip pendapat Kamali bahwa "tidak ada keberatan terhadap kontrak futures karena merupakan kebolehan (ibahah) dalam kerangka hukum Islam, dengan lebih mempertimbangkan kemashalatannya". ${ }^{41}$ Lebih jauh, Kamali berpendapat bahwa kontrak futures memberikan manfaat signifikan bagi ekonomi berbasis pertanian untuk bisa bersaing dengan ekonomi berbasis industri. Futures, menurut Kamali, meningkatkan efisiensi biaya, memberi peluang pelaksanaan perencanaan yang lebih baik, dan sebagai sarana asuransi dalam mengelola risiko dan juga berfungsi sebagai indikator harga. ${ }^{42}$

Dengan kata lain, kontrak futures memberikan manfaat bagi pemenuhan kebutuhan masyarakat, hal mana yang menjadi pertimbangan dalam hukum Islam. Terkait dengan obligasi syariah (sukuk), beberapa pakar syariah menyatakan bahwa sebagian besar sukuk tidak memenuhi prinsip syariah karena melanggar setidaknya satu di antara tiga prinsip. ${ }^{43}$ Dengan demikian, secara efektif sukuk tidak ada bedanya dengan obligasi konvensional, seperti argumentasi dari Muhammad Taqi Uthmani,

\footnotetext{
${ }^{39}$ Abdul Rahim Al-Saati, Sharia Compatible Futures, J.KAU, Islamic Econ, Volume 15, 2002, HIm. 3-25 dalam Salmah Said, Pemikiran Ekonom...Loc.Cit.

${ }^{40}$ Ibid.

${ }^{41}$ Ibid.

${ }^{42}$ Ibid.

${ }^{43}$ Kontrak joalah adalah kontrak antara dua pihak dimana pembeli menyatakan bahwa etika penjual menyerahkan barang yang ditransaksikan pada waktu yang telah disepakati di masa yang akan datang, pembeli akan menyerahkan pembayaran atas barang tersebut kepada penjual, lihat Salmah Said, Derivatives Instruments and Islamic Scholars, Viewpoint, Jurnal Bisnis dan Manajemen Informatika, Volume 4, Nomorv 2 Mei 2011.
} 
Presiden Majelis Syariah AAOIFI (the Accounting and Auditing Organization for Islamic Financial Institutions), Miller, Challoner, Atta (2007), dan Wilson (2008). ${ }^{44}$ Namun, Cakir dan Raei (2007) berpendapat bahwa sukuk berbeda dengan obligasi konvensional karena memberikan manfaat dalam hal meminimalkan risiko ketika investor membentuk porto folio dari sekuritas berpendapatan tetap (fixed income securities). ${ }^{45}$

Salah satu instrumen pasar modal yang juga tidak memenuhi prinsip syariah adalah options, yaitu hak untuk menjual (put options) atau membeli (call options) sekuritas (utamanya saham) di masa yang akan datang dengan harga yang telah ditentukan saat ini. ${ }^{46}$ Mahmoud El Gamal, Tariqullah Khan serta Muhammad Taqi Uthmani, memiliki pendapat yang sama bahwa options mengandung unsur gharar, maysir, dan jahl. ${ }^{47}$

\section{ANALISAN DAN PEMBAHASAN 2}

\section{Fatwa Dewan Syariah Nasional yang Mengatur Tentang Kegiatan Investasi Syariah}

Apabila melihat dalam Al Qur'an dan Hadist sebagai sumber utama ajaran Islam maka dapat diketahui beberapa ketentuan mengenai hal tersebut:

“...Allah telah menghalalkan jual beli dan mengharamkan riba...” (Q.S. 2:275)

"Hai orang yang beriman, jaunganlah kamu saling memakan harta sesamamu dengan jalan yang bathil, kecuali dengan jalan perniagaan yang berlaku dengan suka sama suka diantarakamu..." (Q.S. 4:29).

"Hai orang yang beriman, penuhilah akad-akad itu..." (Q.S. 5:1)

Rasulullah Saw melarang jual beli (yang mengandung) gharar" (HR Al Baihaqi dari Ibnu Umar). "Tidak boleh menjual sesuatu hingga kamu memiliki” (HR Baihaqi dari Hukaimbin Hizam).

\footnotetext{
${ }^{44}$ Salmah Said, Pemikiran Ekonom...Loc.Cit, HIm. 8.

${ }^{45}$ Ibid.

${ }^{46}$ Ibid.

${ }^{47}$ Ibid.
} 
Berdasarkan Al-Qur'an, Hadist dan pendapat para ahli fiqh (ajaran Islam), sesuatu yang dilarang atau diharamkan: ${ }^{48}$

"1. Haram karena bendanya (zatnya). Pelarangan kegiatan muamalah ini disebabkan karena benda atau zat yang menjadi objek dari kegiatan tersebut berdasarkan ketentuan al Qur'an dan Hadist telah dilarang/diharamkan. Benda-benda tersebut, antara lain: babi, khamr (minuman keras), bangkai binatang, dan darah.

2. Haram selain karena bendanya (zatnya). Pengertian dari pelarangan atas kegiatan ini adalah suatu kegiatan yang objek dari kegiatan tersebut bukan merupakan benda-benda yang diharamkan karena zatnya artinya bendabenda tersebut benda-benda yang dibolehkan (dihalalkan). Akan tetapi, benda tersebut menjadi diharamkan disebabkan adanya unsur: tadlis, taghrir/gharar

3. Riba. Terjadinya ikhtikar dan bay najash

4. Tidak sahnya akadnya. Seperti halnya dengan pengharaman disebabkan karena selain zatnya maka pada kegiatan ini benda yang dijadikan objeknya adalah benda yang berdasarkan zatnya dikategorikan halal (dibolehkan), tetapi benda tersebut menjadi haram disebabkan akad atau penjanjian yang menjadikan dasar atas transaksi tersebut dilarang/diharamkan oleh ajaran Islam. Perjanjian-perjanjian tersebut, antara lain: Ta'aluq, terjadi suatu perjanjian di mana pelaku, objek dan periodenya sama".

Fatwa Dewan Syariah Nasional (DSN) yang mengatur tentang kegiatan investasi syariah terdapat karekteristik tersendiri dalam melakukan investasi syariah, termasuk juga di sektor pasar modal. Batasan tersebut adalah berupa kesesuaian suatu produk investasi atas prinsip-prinsip ajaran Islam. DSN suatu lembaga di bawah MUI (Majelis Ulama Indonesia) yang dibentuk tahun 1999 telah megeluarkan ketentuan mengenai kegiatan investasi di pasar modal syariah. Ketentuan tersebut dituangkan ke dalam beberapa fatwa MUI tentang kegiatan investasi yang sesuai syariah ke dalam produkproduk investasi di Pasar Modal Indonesia. Fatwa DSN Nomor: 40/DSN-MUI/X/2003

\footnotetext{
${ }^{48}$ Tim Studi Tentang Investasi Syariah di Pasar Modal Indonesia, Studi Tentang Investasi Syariah di Pasar Modal Indonesia, Jakarta, Departemen Keuangan Republik Indonesia Badan Pengawas Pasar Modal Proyek Peningkatan Efisiensi Pasar Modal Tahun Anggaran 2004, HIm. 12-13.
} 
tanggal 4 Oktober 2003 tentang Pasar Modal dan Pedoman Umum Penerapan Prinsip Syariah di Bidang Pasar Modal ${ }^{49}$ telah menentukan tentang kriteria produk-produk investasi yang sesuai dengan ajaran Islam. Pada intinya, produk tersebut harus memenuhi syarat, seperti: jenis usaha, produk barang dan jasa yang diberikan serta cara pengelolaan perusahaan emiten tidak merupakan usaha yang dilarang oleh prinsipprinsip syariah, antara lain:

1. Usaha perjudian atau permainan yang tergolong judi atau perdagangan yang dilarang. Lembaga keuangan konvensional (ribawi), termasuk perbankan dan asuransi konvensional. Produsen, distributor, serta pedagang makanan dan minuman haram. Produsen, distributor, dan/atau penyedia barang/jasa yang merusak moral dan bersifat mudarat.

2. Jenis transaksi harus dilakukan menurut prinsip kehati-hatian serta tidak diperbolehkan melakukan spekulasi yang di dalamnya mengandung unsur dharar, gharar, maysir, dan zhulm meliputi: najash, ba'i al ma'dun, insider trading, menyebarluaskan informasi yang menyesatkan untuk memperoleh keuntungan transaksi yang dilarang, melakukan investasi pada perusahaan yang pada saat transaksi tingkat (nisbah) utang perusahaan kepada lembaga keuangan ribawi lebih dominan dari modalnya, margin trading dan ikhtikar.

Berdasarkan ketentuan tersebut maka produk-produk investasi di pasar modal yang sesuai prinsip syariah tersebut dapat berupa: ${ }^{50}$

1. Saham

Produk investsi berupa saham pada prinsipnya sudah sesuai dengan ajaran Islam. Dalam teori percampuran, Islam mengenal akad syirkah atau musyarakah, yaitu suatu kerja sama antara dua atau lebih pihak untuk melakukan usaha di mana masing-masing pihak menyetorkan sejumlah dana, barang atau jasa. Adapun jenis-jenis syirkah yang dikenal dalam ilmu fikih, yaitu: 'inan, mufawadhah, wujuh, abdan, mudharabah. Pembagian tersebut didasarkan pada jenis setoran masing-masing pihak dan siapa diantara pihak tersebut yang mengelola kegiatan usaha tersebut.

\footnotetext{
49 Dewan Syariah Nasional, Himpunan Fatwa Dewan Syariah Nasional, Jakarta, Bank Indonesia-Dewan Syariah Nasional, 2003, HIm. 263.

50 Tim Studi Tentang Investasi Syariah di Pasar Modal Indonesia, Studi Tentang Investasi...Op.Cit.,. HIm. 16-18.
} 
Fatwa di atas telah menentukan bagaimana memilih saham-saham yang sesuai dengan ajaran Islam. Dalam perkembangannya telah banyak negara-negara yang telah menentukan batasan suatu saham dapat dikategorikan sebagai saham syariah. Misalnya Malaysia, Amerika serikat melalui Dow Jones Islamic Index. Sementara itu, beberapa institusi keuangan dunia telah membuat pula batasan-batasan untuk kategori saham syariah antara lain: Citi Asset Management Group, Wellington Management Company, Islamic.com dan sebagainya.

\section{Obligasi}

Obligasi berdasarkan definisinya adalah suatu surat berharga jangka panjang yang bersifat utang yang dikeluarkan oleh emiten kepada pemegang obligasi dengan kewajiban membayar bunga pada periode tertentu dan melunasi pokok pada saat jatuh tempo kepada pemegang obligasi.

Berdasarkan definisi tersebut maka dapat dikatakan bahwa obligasi adalah suatu produk yang tidak sesuai ajaran Islam. Menurut ajaran Islam maka suatu utang piutang termasuk kegiatan tabarru (kebajikan), sehingga diharamkan untuk mendapatkan sesuatu dari kegiatan tersebut. Misalnya seseorang meminjam uang Rp 1.000.000,00 maka yang memberikan pinjaman tidak boleh meminta kelebihan dana dari pinjaman tersebut.

Pengertian ini sangat bertentangan dengan pengertian obligasi yang dikenal sekarang. Hal ini dikarenakan obligasi biasanya digunakan untuk kegiatan usaha/bisnis. Dalam ajaran Islam kegiatan usaha/bisnis diketegorikan kegiatan tijarah. Secara logika apabila seseorang meminjan dana untuk kegiatan bisnis maka pihak yang meminjamkan berhak atas sebagian keuntungan atas usaha tersebut.

Sebagai solusi dari permasalahan tersebut maka DSN melalui fatwa Nomor: 32/DSN-MUI/IX/2002 tanggal 14 September 2002 tentang Obligasi Syariah telah melakukan redifinisi dari pengertian obligasi. Pengertian obligasi syariah dalam fatwa tersebut adalah suatu surat berharga jangka panjang berdasarkan prinsip syariah yang dikeluarkan emiten kepada pemegang obligasi syariah yang mewajibkan emiten untuk membayar pendapatan kepada pemegang obligasi syariah berupa bagi hasil/margin/fee serta membayar kembali dana obligasi pada saat jatuh tempo. 


\section{Reksa dana}

Reksa dana adalah wadah yang dipergunakan untuk menghimpun dana dari masyarakat pemodal untuk selanjutnya diinvestasikan dalam portofolio efek oleh manajer investasi. Fatwa DSN Nomor: 20/DSN-MUI/IX/2000 tanggal 18 April 2000 tentang Pedoman Pelaksanaan Investasi Untuk Reksa Dana Syariah telah mendefinisikan tentang reksa dana syariah adalah reksa dana yang beroperasi menurut ketentuan dan prinsip syariah Islam, baik dalam bentuk akad antara pemodal sebagai milik harta (shahib al-mal/rabb al-maal) dengan manajer investasi sebagai wakil shahib al-mal, maupun antara manajer investasi sebagai wakil shahib al-mal dengan pengguna investasi.

Berdasarkan hal tersebut maka batasan untuk produk-produk yang dapat dijadikan porto folio bagi reksa dana syariah adalah produk-produk investasi sesuai dengan ajaran Islam.

\section{ANALISA DAN PEMBAHASAN 3}

\section{Peluang dan Tantangan Investasi Pasar Modal Syariah di Indonesia di Tengah Pandemi Covid-19.}

Pengembangan ekonomi syariah di Indonesia lebih bersifat market driven dan dorongan botton up dalam memenuhi kebutuhan masyarakat. Dengan demikian, pengembangan ekonomi syariah di Indonesia lebih bertumpu pada sektor riil, dan ini merupakan suatu kelebihan tersendiri bagi lembaga keuangan syariah di Indonesia. Hal ini yang menjadikan lembaga keuangan syariah lebih tahan menghadapi krisis covid-19 dibandingkan dengan lembaga keuangan konvensional. Deputi Bidang Ekonomi Kementerian PPN/Bappenas, Bambang Prijambodo menyampaikan dampak Covid-19 sangat terasa ke semua instrumen pasar modal, tapi instrumen syariah lebih kebal pada pandemi. ${ }^{51}$ Kapitalisasi pasar saham syariah secara year to date (ytd) tercatat $-22,39$ persen sementara konvensional sebesar -23,55 persen. Kinerja pasar saham syariah (ytd) tercatat $-16,33$ persen dan saham konvensional jatuh lebih dalam sebesar -20,60

\footnotetext{
${ }^{51}$ https://republika.co.id/berita/qbx6k9396/pasar-modal-syariah-lebih-kebal-di-tengah-pandemi, diakses terakhir Senin, 07 Desember 2020, Pukul 10.00 WIB.
} 
persen. Keunggulan keuangan syariah Indonesia lainnya yaitu regulatori regime yang dinilai lebih baik. Hal ini dikarenakan di Indonesia yang memiliki kewenangan untuk mengeluarkan fatwa terpusat pada Dewan Syariah Nasional (DSN) dan Majelis Ulama Indonesia (MUI), sedangkan di negara lain dapat dikeluarkan oleh perorangan ulama sehingga peluang terjadinya perbedaan sangat besar. Sampai saat ini pemerintah telah menerbitkan tiga UU tetang perbankan Syariah yaitu UU No 7 tahun 1992, UU No 10 tahun 1998, dan UU No 21 tahun 2008. Sedangkan DSN-MUI telah mengeluarkan 119 fatwa terkait ekonomi Syariah.

Pada sisi lain, harus diakui bahwa masih terdapat beberapa permasalahan mendasar yang menjadi kendala berkembangnya pasar modal yang berprinsip syariah di Indonesia. Kendala-kendala dimaksud diantaranya adalah selain masih belum meratanya pemahaman dan atau pengetahuan masyarakat Indonesia tentang investasi di pasar modal yang berbasis syariah, juga belum ditunjangnya dengan peraturan yang memadai tentang investasi syariah di pasar modal Indonesia serta adanya anggapan bahwa untuk melakukan investasi di pasar modal syariah dibutuhkan biaya yang relatif lebih mahal apabila dibandingkan dengan investasi pada sektor keuangan lainnya. Dalam mengembangkan pasar modal syariah di Indoensia, ada beberapa kendala yang dihadapi antara lain :

1) Selama ini pasar modal syariah lebih populer sebagai sebuah wacana dimana banyak bicara tentang bagaimana pasar yang disyariahkan. Dimana selama ini praktek pasar modal tidak bisa dipisahkan dari riba, maysir dan gharar, dan bagaimana memisahkan ketiganya dari pasar modal.

2) Sosialisasi instrumen syariah di pasar modal perlu dukungan dari berbagai pihak.

3) Karena ternyata perkembangan Jakarta Islamic Index dan reksadana syariah kurang tersosialisasi dengan baik sehingga perlu dukungan dari berbagai pihak, khususnya praktisi dan akademisi. Praktisi dapat menjelaskan keberadaan pasar modal secara pragmatis sedangkan akademisi bisa menjelaskan secara ilmiah.

Beradasarkan pada kendala-kendala di atas maka strategi yang perlu dikembangkan, yaitu : 
1) Perlu keaktifan dari pelaku bisnis (pengusaha) muslim untuk membentuk kehidupan ekonomi yang islami. Hal ini guna memotivasi meningkatkan image pelaku pasar terhadap keberadaan instrumen pasar modal yang sesuai dengan syariah.

2) Diperlukan rencana jangka pendek dan jangka panjang oleh Otoritas Jasa Keuangan (OJK) untuk mengakomodir perkembangan instrumen-instrumen syariah dalam pasar modal.

3) Perlu kajian-kajian ilmiah mengenai pasar modal syariah, oleh karena itu dukungan akademisi sangat diperlukan guna memahamkan perlunya keberadaan pasar modal syariah.

\section{KESIMPULAN}

1. Pemikiran Muslim tentang pasar modal syariah memiliki pendapat yang berbeda dalam menilai apakah transaksi sekuritas dalam pasar modal syariah mengandung unsur-unsur yang dilarang secara syariah.

2. Fatwa Dewan Syariah Nasional yang mengatur tentang kegiatan investasi syariah adalah Nomor : 40/DSN-MUI/X/2003 tanggal 4 Oktober 2003 tentang Pasar Modal dan Pedoman Umum Penerapan Prinsip Syariah di Bidang Pasar Modal telah menentukan tentang kriteria produk-produk investasi yang sesuai dengan ajaran Islam.

3. Peluang investasi pasar modal syariah di Indonesia tetap positif di tengah tekanan dampak pandemi Covid-19. Hal itu terlihat dari dominasi pasar saham syariah pada sisi volume, frekuensi, dan nilai transaksi.

\section{DAFTAR PUSTAKA}

Abdul Djalal. 1990. Urgensi Tafsir Maudlin'i Pada Masa Kini. Jakarta: Kalam Mulia. Andri Soemitra. 2009. Bank dan Lembaga Keuangan Syariah. Edisi Pertama. Jakarta: Kencana.

Burhanuddin Susanto. 2009. Pasar Modal Syariah: Tinjauan Hukum. Yogyakarta: UII Press. 
Dewan Syariah Nasional. 2003. Himpunan Fatwa Dewan Syariah Nasional. Jakarta: Bank Indonesia-Dewan Syariah Nasional.

Hamka. 1983. Tafsir Al-Azhar Juz V. Jakarta: Pustaka Panjimas.

M. Quraish Shihab. 2002. Tafsir Al-Misbah: Pesan, Kesan, dan Keserasian Al-Qur'an. Jakarta: Lentera Hati

Nurul Huda dan Mustafa Edwin Nasution. 2007. Investasi pada Pasar Modal Syariah. Jakarta: Kencana.

Obiyathullah Ismath Bacha. Derivative Instruments and Islamic Finance: Some Thoughts for A Reconsideration. International Journal of Islamic Financial Services. Volume 1. Nomor 1. 1999.

Salmah Said. Pemikiran Ekonom Muslim Tentang Pasar Modal Syariah. Jurnal AlFikr. Volume 16. Nomor 2 Tahun 2012.

, Derivatives Instruments and Islamic Scholars, Viewpoint. Jurnal Bisnis dan Manajemen Informatika. Volume 4. Nomor 2 Mei 2011.

Saptono Budi Satrio, 2005. Optimasi Portofolio Saham Syariah (Studi Kasus Bursa Efek Jakarta Tahun 2002-2004). Tesis Program Pascasarjana PSKTTI-UI Jakarta.

Syekh. H. Abdul Halim Hasan Binjai. 2006. Tafsir Al-Ahkam. Jakarta: Kencana.

Tim Studi Tentang Investasi Syariah di Pasar Modal Indonesia. 2004. Studi Tentang Investasi Syariah di Pasar Modal Indonesia. Jakarta: Departemen Keuangan Republik Indonesia Badan Pengawas Pasar Modal Proyek Peningkatan Efisiensi Pasar Modal.

Zamir Iqbal dan Abbas Mirakhor. 2008. Pengantar Keuangan Islam: Teori dan Praktik, Jakarta: Kencana. 